\title{
Diarrhoeagenic Escherichia coli and other causes of childhood diarrhoea: a case-control study in children living in a wastewater-use area in Hanoi, Vietnam
}

Correspondence

Bui Thi Thu Hien

hien.nihe@gmail.com

Received 23 November 2006

Accepted 10 April 2007

\author{
Bui Thi Thu Hien, ${ }^{1,2}$ Do Thuy Trang, ${ }^{1}$ Flemming Scheutz, ${ }^{3}$ \\ Phung Dac Cam, ${ }^{1}$ Kåre Mølbak ${ }^{4}$ and Anders Dalsgaard ${ }^{2}$
}

\author{
${ }^{1}$ Department of Microbiology, National Institute of Hygiene and Epidemiology, Hanoi, Vietnam \\ ${ }^{2}$ Department of Veterinary Pathobiology, Faculty of Life Science, Copenhagen University, \\ Frederiksberg, Denmark \\ ${ }^{3}$ International Escherichia and Klebsiella Centre (WHO), Department of Bacteriology, Mycology, \\ and Parasitology, Statens Serum Institut, Copenhagen, Denmark
}

${ }^{4}$ Department of Epidemiology, Statens Serum Institut, Copenhagen, Denmark

\begin{abstract}
A case-control study was conducted to identify the aetiology of diarrhoeal diseases in pre-school children in a suburban area of Hanoi where the use of untreated wastewater in agriculture and aquaculture is a common practice. Stool specimens and clinical information were collected from 111 pairs of children with diarrhoea and healthy controls. A total of 73 cases $(66 \%)$ and 41 controls $(36 \%)$ had an enteric pathogen. The pathogens most often associated with diarrhoea were rotavirus (17\% of cases) and Entamoeba histolytica (15\%), followed by Shigella (5\%). Diarrhoeagenic Escherichia coli (DEC) was found in $23 \%$ of both patients and controls.

Characterization of DEC by serotyping, antimicrobial susceptibility test and PFGE showed that DEC represented by different pathotypes belonged to various serotypes. Except for three enterotoxigenic $E$. coli strains, typing by PFGE revealed no correlation between pathotype and serotype of DEC strains. This suggests a high prevalence of a variety of DEC subtypes in this area. For this particular region, vaccine development strategies targeting rotavirus and Shigella are likely to be of public health benefit, whereas the role of DEC and preventive measures need to be further elaborated.
\end{abstract}

\section{INTRODUCTION}

Diarrhoeal disease is a major problem throughout the world, and is responsible for high morbidity and mortality among children, especially in developing countries. Some aetiological studies of diarrhoeal diseases have been carried out in Vietnam (Isenbarger et al., 2001; Nguyen et al., 2005a), but not in areas where untreated wastewater is used in agriculture and aquaculture. The association of wastewater use and risks to human health has been assessed in various countries such as Israel, Morocco, Mexico and Pakistan, where wastewater is also commonly used for irrigation (Shuval et al., 1989; Feenstra et al., 2000; Habbari et al., 2000; Blumenthal et al., 2001; WHO, 2006). Some

Abbreviations: A/EEC, attaching and effacing Escherichia coli; DEC, diarrhoeagenic E. coli; EAF, EPEC adherence factor; EAggEC, enteroaggregative E. coli; EIEC, enteroinvasive E. coli; EPEC, enteropathogenic E. coli; ETEC, enterotoxigenic E. coli; NIHE, National Institute of Hygiene and Epidemiology; VTEC, Vero cytotoxin-producing E. coli. studies have highlighted a high risk of being infected with intestinal parasites and of getting diarrhoeal diseases, especially in small children who live in the wastewaterusing areas (Cifuentes, 1998; Cifuentes et al., 2000).

In a hospital study, the prevalences of diarrhoeagenic Escherichia coli (DEC) were 22.5 and $12 \%$ in the diarrhoea and control groups, respectively, but mainly due to a high frequency of enteroaggregative E. coli (EAggEC) (Nguyen et al., 2005a). Using dot-blot hybridization in another hospital-based study, eae-positive E. coli were found at a significantly higher prevalence in children with diarrhoea than in asymptomatic controls (Bodhidatta et al., 2007). In a study outside Hanoi, Campylobacter and Shigella were found to be associated with diarrhoea, and enterotoxigenic E. coli (ETEC) was the prevalent group of DEC (Isenbarger et al., 2001). None of these studies included detailed characterization of DEC.

The aim of the present study was to determine the aetiology of diarrhoeal diseases in children from families engaged in 
wastewater-irrigated agriculture or aquaculture activities in a suburban area of Hanoi, Vietnam. In particular, we aimed to determine the role of DEC by carrying out a detailed characterization.

\section{METHODS}

Study area. The study was conducted in Yen So commune (population 10500 ), a south-east suburban area of Hanoi city with a long tradition for using untreated wastewater for irrigation in agriculture and for fishpond culture. Most of the city wastewater, mainly household sewage and industrial effluent, is discharged into three main canals, which run through this low-lying area before the wastewater reaches the recipient rivers. Wastewater-irrigated fish and vegetables are produced at low cost, seem widely accepted by the consumers and make a significant contribution to household economies (Hoan, 1996; Thang, 1996).

Study design and data collection. The parents of children under 72 months of age living in 400 randomly selected households were invited to let their children participate. This cohort of children was monitored from the middle of November 2002 to the end of May 2004 by weekly recall interviews. Trained field workers collected data on episodes of diarrhoeal disease, including date of onset, length of the episode, symptoms and treatment. An episode of acute diarrhoea was defined as: (i) at least three or more loose (or watery) stools within a $24 \mathrm{~h}$ period, regardless of other gastrointestinal symptoms; or (ii) two or more loose stools associated with at least one other symptom of gastrointestinal infection (abdominal pain, cramping, nausea, vomiting or fever); or (iii) passage of a single loose stool with grossly evident blood/mucous (Isenbarger et al., 2001). Two independent episodes were separated by at least 3 days that were diarrhoea-free. An episode of diarrhoea with a duration of 14 days or more was regarded as an episode of persistent diarrhoea (Mølbak et al., 1997).

For every recruited case, a control was randomly selected among the children residing in the 400 houses. An eligible control was a member of the cohort, but not living in the same house with the case, and who had not had diarrhoea in the preceding 4 weeks. Similarly, a control could later become a case if he/she developed diarrhoea within the specified period.

Faecal specimen collection. On the day that a case or control was ascertained, a stool sample was collected from the child. Stools were collected in plastic containers for parasitological and viral analyses, and in Cary-Blair transport medium (Difco Laboratories) for bacteriological analyses. When a specimen was unavailable, we collected rectal swabs and transferred them to Cary-Blair transport medium. Samples were stored in a refrigerator at the communal health station until transportation in cold boxes to the laboratory of the National Institute of Hygiene and Epidemiology (NIHE), Hanoi, on the day of collection.

Microbiological analysis of stools. Stools were processed and analysed for enteric bacteria and protozoan parasites at the laboratory of the NIHE on the day of sample collection. Standard culture and identification methods were used to identify enteric pathogens (WHO, 1987). In brief, Entamoeba histolytica, Giardia lamblia and Cyclospora spp. were identified by direct microscopy of a wet mount. Samples suspected to be positive for Cyclospora were confirmed by fluorescent microscopy. Stool specimens were tested for rotavirus with the IDEIA ELISA kit (Dako) as described by the manufacturer. Stools from Cary-Blair transport medium were cultured on SSI enteric medium (Blom et al., 1999) for the isolation of E. coli. Suspected E. coli colonies from SSI medium were further identified by a few selected biochemical tests: use of Simmons citrate, gas and hydrogen sulfide production, and lactose and glucose fermentation. Colonies that grew in Simmons citrate and/or produced gas and hydrogen sulfide and/or did not ferment glucose were discarded. Hektoen enteric agar plates were used to isolate Shigella spp. and thiosulfate citrate bile sucrose agar plates for Vibrio spp. Faecal samples were also inoculated into selenite F and Doyle's enrichment broth prior to subculture on Brucella agar (5\% sheep blood) and Hektoen agar plates for the selection of Salmonella and Campylobacter, respectively. All agar plates and enrichment broths were incubated at $37^{\circ} \mathrm{C}$ for $18-$ $24 \mathrm{~h}$. The microbiological media used were either from Difco Laboratories or from Becton Dickinson, except for the SSI enteric medium (Statens Serum Institut).

Shigella spp., Salmonella spp. and Vibrio spp. were identified by biochemical tests and antiserum agglutination (all antisera were from S\&A Reagents Lab). Campylobacter spp. were isolated by membrane filtration using cellulose triacetate membranes with a $0.45 \mu \mathrm{m}$ pore size placed on Brucella agar ( $5 \%$ sheep blood; NIHE) plates, which were incubated at $42.0 \pm 0.5{ }^{\circ} \mathrm{C}$ for $48 \mathrm{~h}$ under microaerophilic conditions (CampyGen CN25; Oxoid) (Steele \& McDermott, 1984). The suspect colonies were examined by microscopy following Gram staining (Wang \& Murdoch, 2004) and considered to be Campylobacter spp. when curve-shaped and motile bacteria were observed, and a positive catalase and oxidase reaction was found. Campylobacter jejuni and Campylobacter coli were differentiated based on the results of a hippurate hydrolysis test (Bolton et al., 1992).

Characterization of DEC by multiplex PCR and dot-blot hybridization. Multiplex PCRs with eight different primers were carried out at the NIHE, Hanoi, to identify the type of DEC (and Shigella) (Table 1). The criteria for determining the different types of DEC by PCR were as follows: the presence of eltB and/or est $A$ genes was used to detect ETEC, the presence of $v t x 1$ and/or $v t x 2$ to detect Vero cytotoxin-producing E. coli (VTEC), the presence of eae to detect attaching and effacing $E$. coli (A/EEC), the presence of $b f p A$ to detect enteropathogenic E. coli (EPEC) plasmids, the presence of $i p a H$ to detect enteroinvasive E. coli (EIEC) and Shigella, and the presence of aatA (formerly CVD432) to detect EAggEC. Five to seven colonies selected from each primary plate were subcultured on nutrient slant agar (Difco) and incubated overnight at $37^{\circ} \mathrm{C}$. Bacterial cultures from the five to seven slant agars were suspended in PBS to 1 McFarland standard $\left(10^{8}\right.$ bacteria $\left.\mathrm{ml}^{-1}\right)$ and boiled for $10 \mathrm{~min}$, followed by centrifugation at $13000 \mathrm{~g}$ for $5 \mathrm{~min}$. Two microlitres of the DNA template was amplified in a final volume of $20 \mu \mathrm{l}$ containing $0.5 \mathrm{mM}$ each dNTP, $2 \mu \mathrm{l}$ PCR buffer [150 mM Tris/HCl ( $\mathrm{pH} 8.0$ ), $500 \mathrm{mM} \mathrm{KCl}$ ], $1.2 \mu \mathrm{l} 25 \mathrm{mM} \mathrm{MgCl}_{2}, 1.6 \mu \mathrm{l}$ each $2.5 \mu \mathrm{mol}$ primer mix and $0.5 \mathrm{U}$ Taq Gold DNA polymerase. The PCR was carried out in a DNA thermal cycler 480 (Perkin Elmer) with 30 cycles of $94{ }^{\circ} \mathrm{C}$ for $40 \mathrm{~s}, 53{ }^{\circ} \mathrm{C}$ for $1 \mathrm{~min}$ and $72{ }^{\circ} \mathrm{C}$ for $1 \mathrm{~min}$. PCR products $(10 \mu \mathrm{l})$ were then electrophoresed on $1.5 \%(\mathrm{w} / \mathrm{v})$ agarose gel (Gibco Life Technologies) at $120 \mathrm{mV}$ for $30 \mathrm{~min}$ and visualized with a UV transilluminator after ethidium bromide staining. If the pooled DNA template result was negative following gel electrophoresis, the sample was considered negative for DEC. If bands were seen after gel electrophoresis, the band sizes were compared with the sizes of marker bands to identify the DEC type. If a mixed bacterial culture was PCR positive, then the DEC type was determined for individual E. coli isolates collected from the slant agars and subcultured onto MacConkey agar (Difco) before PCR with single primer sets.

All PCR-positive strains were transferred to the Statens Serum Institut to verify the DEC type. Strains were examined for the presence of virulence genes using DNA probes derived from: NTP705, Vero cytotoxin 1 ( vtx1) (Willshaw et al., 1985); DEP28, Vero cytotoxin 2 (vtx2) (Thomas et al., 1991); pSS126, the enteroaggregative heat stable 
Table 1. PCR primers used for the identification of different types of DEC

\begin{tabular}{|c|c|c|c|c|c|}
\hline DEC type & Target gene & Primer & Primer sequence $\left(5^{\prime} \rightarrow 3^{\prime}\right)$ & Amplicon size (bp) & Reference \\
\hline \multirow[t]{4}{*}{ ETEC } & eltB & LT1 & TCTCTATGTGCATACGGAGC & 322 & Svenungsson et al. (2000) \\
\hline & & $\mathrm{LTr}$ & CCATACTGATTGCCGCAAT & & \\
\hline & estB & STI2 1 & GCTAAACCAGTAG $_{A}$ GGTCTTCAAAA & 147 & Svenungsson et al. 2000) \\
\hline & & STI2 r & CCCGGTACAG $_{\mathrm{A}}$ GCAGGATTACAACA & & \\
\hline \multirow[t]{4}{*}{ VTEC } & $v t x 1$ & VT1 1 & GAAGAGTCCGTGGGATTACG & 130 & Svenungsson et al. (2000) \\
\hline & & VT1 r & AGCGATGCAGCTATTAATAA & & \\
\hline & $v t \times 2$ & VT2 1 & ACCGTTTTTCAGATTTTG ${ }_{A}$ CACATA & 298 & Svenungsson et al. 2000) \\
\hline & & VT2 r & TACACAGGAGCAGTTTCAGACAGT & & \\
\hline \multirow[t]{4}{*}{ EPEC } & eae & eae u & CACACGAATAAACTGACTAAAATG & 376 & Svenungsson et al. (2000) \\
\hline & & eae 1 & AAAAACGCTGACCCGCACCTAAAT & & \\
\hline & bfpA & bfp A2 u & TTCTTGGTGCTTGCGTGTCTTTT & 367 & Svenungsson et al. (2000) \\
\hline & & bfp A2 1 & TTTTGTTTGTTGTATCTTTGTAA & & \\
\hline \multirow[t]{2}{*}{ EIEC } & ipaH & IpaH III & GTTCCTTGACCGCCTTTCCGATACCGTC & 620 & Sethabutr et al. (1993) \\
\hline & & IpaH IV & GCCGGTCAGCCACCCTCTGAGAGTAC & & \\
\hline \multirow[t]{2}{*}{ EAggEC } & aat $A$ & EA1 & CTGGCGAAAGACTGTATCAT & 630 & Schmidt et al. (1995) \\
\hline & & EA2 & CAATGTATAGAAATCCGCTGTT & & \\
\hline
\end{tabular}

toxin (astA) (Savarino et al., 1996); CVD419, the plasmid-encoded enterohaemolysin (ehxA) (Levine et al., 1987); PS2.5, the invasive plasmid in EIEC (Small \& Falkow, 1986); WR390, the invasion plasmid antigen gene ipaH found in EIEC and Shigella (Venkatesan et al., 1989); CVD432, the plasmid marker aatA encoding a dispersin translocator (Nishi et al., 2003) for EAggEC (Baudry et al., 1990); SLM862, detecting the daaC gene from the daa locus encoding the afimbrial adhesin F1845, mediating diffuse adherence of E. coli (Bilge et al., 1989); DAS100 (heat-stable enterotoxin human variant estAh), DAS101 (heat-stable enterotoxin, porcine variant estAp) and G119 (heat-labile enterotoxin eltB); and JPN16, the plasmid marker EPEC adherence factor (EAF) gene probe (Nataro et al., 1985), MSD207 detecting the bundle-forming pilus gene (bfpA) (Girón et al., 1993) and CVD434, E. coli attaching and effacing gene (eae) (Jerse et al., 1990). Only dot-blot-positive E. coli strains were characterized further as described below.

Serotyping. Identification of somatic $(\mathrm{O})$ and flagella $(\mathrm{H})$ antigens was carried out by tube and microtitre-plate agglutination with the specific antisera O1-O181, supplemented with the presumptive new O groups OX182-OX186, and H1-H56 using methods described by Ørskov \& Ørskov (1984).

Antimicrobial susceptibility testing by MIC. Antimicrobial susceptibility testing was carried out for 40 DEC and 6 Shigella spp. using Sensititre (TREK Diagnostic Systems), a commercially available MIC technique using dehydrated antimicrobials in microtitre wells. The wells were inoculated and incubated according to the Clinical and Laboratory Standards Institute (CLSI) (formerly the National Committee for Clinical Laboratory Standards) (NCCLS, 1997). The MIC was defined as the lowest concentration of antimicrobial with no visible bacterial growth and the breakpoints used are shown in Table 2. E. coli ATCC 25922 was used for quality control and the MIC values for the strains were evaluated in accordance with CLSI guidelines.

PFGE. The PulseNet method of the Centers for Disease Control and Prevention (PulseNet USA, 2004) was used for PFGE typing of the E. coli isolates. XbaI was used for genomic DNA digestion. The fragments obtained with this restriction enzyme were resolved using a contour-clamped homogeneous electric field apparatus (CHEF-II Mapper; Bio-Rad). DNA band patterns were visualized by UV illumination, photographed, analysed and compared using GEL COMPAR II software (Applied Maths). We used the band-based dice similarity coefficient and the UPGMA dendrogram type with a position tolerance setting of $1.5 \%$ for both optimization and band comparison.

Data analysis. Incidence rates of diarrhoea were calculated for the children cohort over the follow-up period. To estimate pathogenicity of the various agents, we estimated the odds ratio by multivariate logistic regression analyses. The analyses were adjusted for age by using an indicator variable for age groups $0-11,12-23$, and $\geqslant 24$ months of age. A level of significance of 0.1 presented by a $90 \%$ confidence interval (CI) was selected. Data were analysed with STATA 8 (Stata).

Ethical considerations. The children were recruited in the study after obtaining informed consent from their parents. The parents

Table 2. Break-point values for MIC testing of different DEC types

\begin{tabular}{|lcc|}
\hline Antimicrobial agent & $\begin{array}{c}\text { Breakpoint } \\
\left(\boldsymbol{\mu} \mathbf{~ m l}^{-\mathbf{1}}\right)\end{array}$ & $\begin{array}{c}\text { Test range } \\
\left(\boldsymbol{\mu} \mathbf{g ~ m l}^{-\mathbf{1}}\right)\end{array}$ \\
\hline Ampicillin (AMP) & 32 & $1-32$ \\
Amoxicillin/clavulanic acid (AUG2) & 32 & $2-32$ \\
Apramycin (APR) & 32 & $4-64$ \\
Ceftiofur (XNL) & 8 & $0.5-8$ \\
Cephalothin (CEP) & 32 & $2-64$ \\
Chloramphenicol (CHL) & 32 & $2-64$ \\
Ciprofloxacin (CIP) & $0.125 / 4$ & $0.03-4$ \\
Colistin (COL) & 16 & $4-64$ \\
Florfenicol (FFN) & 32 & $2-64$ \\
Gentamicin (GEN) & 8 & $1-32$ \\
Nalidixic acid (NAL) & 32 & $8-128$ \\
Spectinomycin (SPE) & 128 & $4-128$ \\
Neomycin (NEO) & 16 & $2-32$ \\
Streptomycin (STR) & 32 & $4-64$ \\
Sulfonamide (SMX) & 512 & $64-1024$ \\
Tetracycline (TET) & 16 & $2-32$ \\
Trimethoprim (TMP) & 16 & $4-32$ \\
\hline
\end{tabular}


were free to decide whether to continue or withdraw their children from the follow-up study at any time during the study period. Medical treatment (oral rehydration solution and certain antimicrobials prescribed by the medical doctor at the communal station) was provided free of charge to any child who developed an episode of diarrhoea. Ethical clearance for the study was provided by the Medical Ethics Committee of NIHE, Hanoi.

\section{RESULTS AND DISCUSSION}

\section{Occurrence of enteric pathogens and incidence of diarrhoea}

A total of 222 children, including 31 newborns, under 72 months old (median age 27 months, mean 30 months, range 1-68 months; $54.6 \%$ boys) from 182 households were enrolled in the 18.5 month follow-up and followed for 101509 days. A total of 173 episodes of diarrhoea was reported during 100743 days at risk, giving an incidence of 0.63 episodes per year at risk. The highest incidence occurred in infants of $<12$ months of age with 1.3 episodes per year. This is lower than morbidity rates reported from prospective studies in 20 countries published between 1990 and 2000 (Kosek et al., 2003), which reported mean global estimates of 2.7 episodes per year in children aged $0-5$ months and 4.8 per year in children aged 6-11 months.

A total of 111 stool specimens from cases, and the same number from controls, were analysed for enteric pathogens. We detected an enteric pathogen in 73 children $(65.7 \%)$ with diarrhoea, compared with 41 controls $(36.9 \%)(P<0.0001$, Table 3). This is higher than some studies where enteric pathogens were found in 46 (el Sheikh \& el Assouli, 2001; El Mohamady et al., 2006), 50 (Mølbak et al., 1994) and 54\%
(Olesen et al., 2005) of cases, and $22 \%$ (Olesen et al., 2005) and $28 \%$ (Ogunsanya et al., 1994) of controls. The findings were similar to other studies (Youssef et al., 2000; Vu Nguyen et al., 2006), including a multi-centre study in five countries (Huilan et al., 1991), but lower than studies in Bangladesh ( $75 \%$ of cases and $44 \%$ of controls) (Albert et al., 1999), Jordan (78\% of cases) (Nimri \& Meqdam, 2004), GuineaBissau (48\% of controls) (Mølbak et al., 1994) and Tanzania (52\% of controls) (Gascon et al., 2000). The majority of these other studies were based on findings from patients seeking medical attention with a general practitioner (Olesen et al., 2005) or at clinics (Ogunsanya et al., 1994; Albert et al., 1999; Gascon et al., 2000), outpatient facilities (el Sheikh \& el Assouli, 2001; Nimri \& Meqdam, 2004; El Mohamady et al., 2006; Vu Nguyen et al., 2006) or inpatient hospitals (Youssef et al., 2000). Only a few were community based as in this study. In Guinea-Bissau, a potential enteropathogen was found in $50 \%$ of 1219 diarrhoeal episodes and $48 \%$ of 511 asymptomatic controls in a 1 year community study of childhood diarrhoea (Mølbak et al., 1994), and in Bangladesh $58 \%$ of stools from children with persistent diarrhoea, $60 \%$ from children with acute diarrhoea and $56 \%$ from healthy controls were positive for enteropathogens (Baqui et al., 1992). These different studies are not all directly comparable, as the microbiological methods were different and the range of pathogens studied varied. One limitation of the present study was the restricted range of gastrointestinal parasites studied (e.g. we did not examine for Cryptosporidium spp.); however, we did include a detailed diagnostic battery for DEC.

Fig. 1 shows the relative monthly prevalence of DEC, Entamoeba histolytica and rotavirus detected in the study in stools from both cases and controls during the 18.5 month

Table 3. Detection of enteric pathogens (DEC genes by multiplex PCR) in stool samples from children with and without diarrhoea living in Yen So commune in peri-urban Hanoi

\begin{tabular}{|lcccl|}
\hline Pathogen & $\begin{array}{c}\text { No. positive (\%) } \begin{array}{c}\text { [no. of DEC strains } \\
\text { isolated for characterization] }\end{array} \\
\end{array}$ & $\begin{array}{c}\text { Odds ratio } \\
(\mathbf{9 5} \% \mathbf{C I})^{*}\end{array}$ & P value $\dagger$ \\
\cline { 2 - 3 } & Cases $(\boldsymbol{n}=\mathbf{1 1 1})$ & Controls $(\boldsymbol{n}=\mathbf{1 1 1})$ & & \\
\hline Rotavirus & $19(17.1)$ & $5(4.5)$ & $4.5(1.6-13.0)$ & $\mathbf{0 . 0 0 6}$ \\
Entamoeba histolytica & $17(15.3)$ & $5(4.5)$ & $4.4(1.8-10.8)$ & $\mathbf{0 . 0 0 6}$ \\
DEC & $25(22.5)[22]$ & $26(23.4)[18]$ & $0.9(0.4-1.8)$ & 0.71 \\
EAggEC & $11[9]$ & $15[12]$ & $0.4(0.1-1.0)$ & 0.051 \\
A/EEC and EPEC & $7[7]$ & $5[5]$ & $2.7(0.7-10.4)$ & 0.1 \\
ETEC & $4[3]$ & $5[1]$ & $1.2(0.3-5.4)$ & 0.79 \\
EIEC & $3[3]$ & $1[0]$ & $2.6(0.4-16.8)$ & 0.3 \\
Shigella spp. & $6(5.4)$ & 0 & & \\
Non-typhoid Salmonella & $4(3.6)$ & $3(2.7)$ & $1.0(0.2-6.3)$ & 0.98 \\
Campylobacter jejuni & 2 & 2 & $1.4(0.1-14.6)$ & 0.76 \\
Total & $73(65.7)$ & $41(36.9)$ & $3.55(1.97-6.42)$ & $\mathbf{0 . 0 0 0 5}$ \\
\hline
\end{tabular}

NA, Not applicable.

* Odd ratios adjusted for gender and age groups $(0-23$ and $\geqslant 24$ months); the reference age group was the children older than 24 months of age.

$\dagger$ Bold indicates a significant difference $(P<0.005)$. 


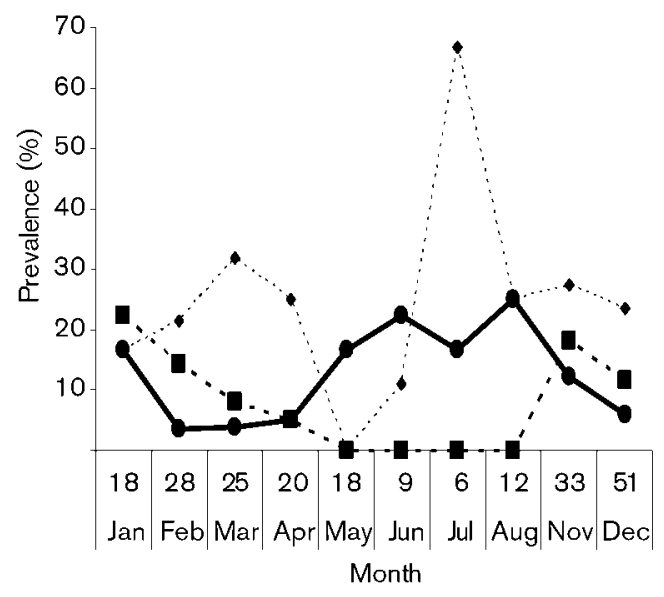

Fig. 1. Relative monthly prevalence of enteropathogens detected in stools from 222 children during an 18.5 month follow-up period in Yen So commune, Hanoi, Vietnam, 2002-2004. Results for September and October are not shown. $\bullet$, DEC; $\mathbf{\square}$, rotavirus; E. histolytica.

follow-up period. The mean number of stools tested per month (except for September and October) was 22 (range 6-51 stools). Rotavirus prevalence was highest during the winter months from October to February, where its seasonal trend was similar to other studies (Nguyen et al., 2004; Van Man et al., 2005). From May to December, DEC and Entamoeba histolytica were detected, with no obvious seasonality. Monthly prevalences of Shigella spp., Salmonella spp. and Campylobacter spp. are not shown in the figure and were distributed sparsely throughout the year.

In order of observed frequency, rotaviruses, Entamoeba histolytica, and Shigella spp. were found at higher prevalences in cases than in controls $(P<0.05$, Table 3$)$. The six cases of Shigella infection included one with Shigella dysenteriae, one double infection with Shigella sonnei and $S$. dysenteriae, and S. sonnei was isolated from the remaining four children. As in other areas of the world, rotavirus is a major cause of diarrhoeal illness, characterized by vomiting and watery diarrhoea. Most of the rotavirus cases were in children less than 3 years of age (15/19 cases). The findings in our study are in concordance with other studies in Vietnam (Nguyen et al., 2001, 2004; Van Man et al., 2005), Thailand (Echeverria et al., 1989, 1994), Denmark (Olesen et al., 2005) and Jordan (Youssef et al., 2000), but not as high as in children less than 12 years in Libya (26.6\%) (Ali et al., 2005). Among the parasites, Entamoeba histolytical Entamoeba dispar was surprisingly common $(15.3 \%$ of cases and $4.5 \%$ of controls) and was associated with diarrhoea (odds ratio of 4.38). This was much higher than the observed $1.8 \%$ from children with acute diarrhoea in Bangladesh (Baqui et al., 1992). A high prevalence of the Entamoeba histolytica/Entamoeba dispar complex (22\%) has been reported from children of less than 14 years in Venezuela (Diaz et al., 2006), and as $11.8 \%$ in children less than 12 years in Libya (Ali et al., 2005). In both studies, increasing age was associated with infection. One limitation of these studies, including our own, however, was that they did not differentiate between Entamoeba histolytica and Entamoeba dispar. This differentiation would be highly relevant in future studies attempting to reassess the epidemiology and transmission of amoebiasis and Entamoeba histolytica in particular, which has been shown to be negatively associated with the growth of pre-school children in Dhaka, Bangladesh (Mondal et al., 2006), and an unusually high incidence of liver abscess in adults in central Vietnam (Blessmann et al., 2002).

Among the bacterial pathogens, Shigella and EIEC, which share clinical and epidemiological features, was the most important group, accounting for $8 \%$ of cases of diarrhoea. This is a relatively high prevalence bearing in mind that the study was community-based where mild cases tend to dominate, and was similar to other findings (Albert et al., 1999; Youssef et al., 2000; Orlandi et al., 2006; Vu Nguyen et al., 2006), but definitely lower than in Libya (Ali et al., 2005). Shigella and EIEC are non-zoonotic bacteria that are transmitted primarily by person-to-person spread, but part of the reason for the high prevalence could also be due to exposure to wastewater contaminated with human faeces. Clinically, the infection was characterized by fever and abdominal pain. Other DEC were also commonly found, but at high rates among both cases and controls. Unexpectedly, ETEC did not have a dominating role. VTEC, Vibrio spp., G. lamblia and Cyclospora spp. were not isolated from any specimen. Seventeen cases $(15.3 \%)$ were infected with more than one enteric pathogen.

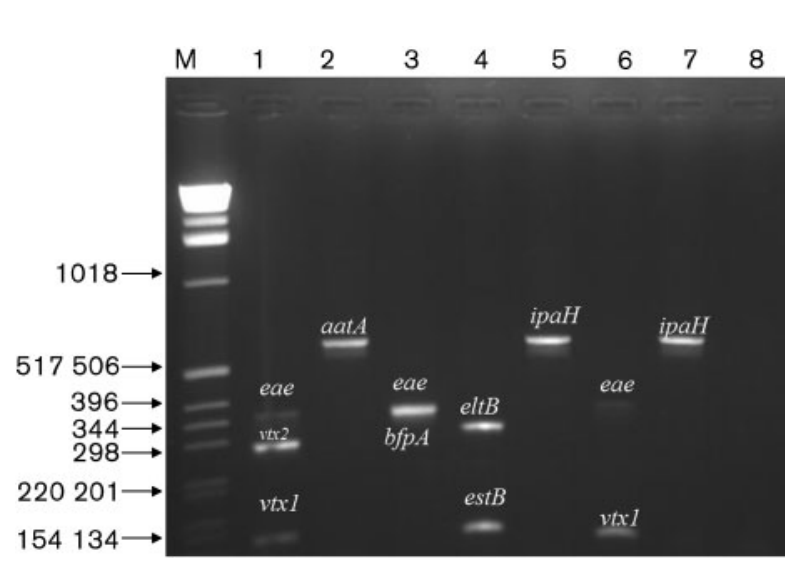

Fig. 2. Multiplex $P C R$ amplification of $D E C$ reference strains from pure cultures. Lanes: 1, VTEC ATCC 43889 (eae, vtx2 and vtx1); 2, EAggEC (aatA); 3, EPEC ATCC 43887 (eae and $b f p A$ ); 4, ETEC ATCC 35401 (eltB and estB); 5, EIEC ATCC 43893 $($ ipaH); 6, VTEC 43890 (eae and $v t \times 1$ ); 7, sample D2842 (ipaH); 8, negative control ATCC 11775; M, DNA marker, with fragment sizes indicated (bp). 


\section{Characterization of DEC}

Fig. 2 shows the band patterns using multiplex PCR obtained with reference strains from pure cultures. Multiplex PCR with the pooled DNA (five to seven colonies from each faecal sample) from a total of 222 faecal samples yielded amplicons for 51 specimens (Table 3). In multiplex PCRs, 11 pools of five to seven colonies from each sample were positive, but isolation of single viable cultures was unsuccessful from 3 cases (two EAggEC and one ETEC) and 8 controls (three EAggEC, four ETEC and one EIEC). Eleven samples therefore could not be tested by dot-blot hybridization. Dot-blot hybridization results of the 40 PCR-positive strains were in accordance with the PCR results. If isolation was unsuccessful, samples were still considered to be positive because of the high sensitivity of the PCR assay (Svenungsson et al., 2000). This was expected, in view of the high sensitivity of PCR in comparison with conventional culture procedures. The presence of other enterotoxin-producing bacteria (e.g. Klebsiella pneumoniae and Citrobacter freundii) could not be excluded, but results from previous studies indicate that

Table 4. Pathogenic group, virulence genes, serotypes and PFGE types of $40 \mathrm{E}$. coli strains isolated from cases of diarrhoea and controls

\begin{tabular}{|c|c|c|c|c|c|}
\hline Number & Pathogenic group & Virulence gene & Serotype & PFGE pattern & Status \\
\hline D2858 & $\mathrm{A} / \mathrm{EEC}$ & eae & $\mathrm{O} 13: \mathrm{NM}$ & NT & Control \\
\hline D2739 & $\mathrm{A} / \mathrm{EEC}$ & eae & O156:NM & 16 & Control \\
\hline D2740 & $\mathrm{A} / \mathrm{EEC}$ & eae & $\mathrm{O} 177: \mathrm{NM}$ & 18 & Control \\
\hline D2990 & $\mathrm{A} / \mathrm{EEC}$ & eae & O rough: $\mathrm{H} 19$ & 11 & Control \\
\hline D2743 & $\mathrm{A} / \mathrm{EEC}$ & $e a e, b f p A$ & $\mathrm{O} 49: \mathrm{H} 10$ & 7 & Control \\
\hline D2725 & $\mathrm{A} / \mathrm{EEC}$ & eae & $\mathrm{O} 158: \mathrm{H} 19$ & 34 & Diarrhoea \\
\hline D2729 & $\mathrm{A} / \mathrm{EEC}$ & eae & $\mathrm{O}$ rough: $\mathrm{NM}$ & 28 & Diarrhoea \\
\hline D2734 & $\mathrm{A} / \mathrm{EEC}$ & eae & O3 : H19 & 19 & Diarrhoea \\
\hline D2736 & $\mathrm{A} / \mathrm{EEC}$ & eae & $\mathrm{O} 49: \mathrm{H} 46$ & 23 & Diarrhoea \\
\hline D2738 & EPEC & eae & $\mathrm{O} 157: \mathrm{NM}$ & 33 & Diarrhoea \\
\hline D2741 & EPEC $^{*}$ & $e a e, b f p A$ & O119: NM & 30 & Diarrhoea \\
\hline D2730 & EPEC $^{*}$ & $e a e, \mathrm{EAF}$ & O111:H9 & 29 & Diarrhoea \\
\hline D2755 & EAggEC & aat $A$ & $\mathrm{O} 86: \mathrm{H} 30$ & 9 & Control \\
\hline D2764 & EAggEC & aat $A$ & O59: NM & 8 & Control \\
\hline D2766 & EAggEC & aat $A$ & $\mathrm{O}+: \mathrm{H} 10$ & 12 & Control \\
\hline D2773 & EAggEC & aat $A$ & $\mathrm{O} 117: \mathrm{H} 37$ & 13 & Control \\
\hline D2778 & EAggEC & aat $A$ & $\mathrm{O}$ rough : $\mathrm{H} 30$ & 10 & Control \\
\hline D2780 & EAggEC & aat $A$ & O6 : H10 & 2 & Control \\
\hline D2781 & EAggEC & aat $A$ & $\mathrm{O} 145: \mathrm{H} 4$ & 15 & Control \\
\hline D2768 & EAggEC & aat $A$, ast $A$ & $\mathrm{O} 14: \mathrm{NM}$ & 5 & Control \\
\hline D2779 & EAggEC & aat $A$, ast $A$ & $\mathrm{O} 134: \mathrm{H} 27$ & NT & Control \\
\hline D2784 & EAggEC & aat $A$, ast $A$ & O15: NM & 6 & Control \\
\hline D2758 & EAggEC & aat $A$, ast $A, \mathrm{EAF}$ & $\mathrm{O} 13: \mathrm{H} 30$ & 4 & Control \\
\hline D2762 & EAggEC & aatA, EAF & $\mathrm{O} 171: \mathrm{NM}$ & 17 & Control \\
\hline D2761 & EAggEC & aat $A$ & $\mathrm{O} 171: \mathrm{H} 7$ & 36 & Diarrhoea \\
\hline D2769 & EAggEC & aat $A$ & $\mathrm{O}$ rough : H31 & 25 & Diarrhoea \\
\hline D2775 & EAggEC & aat $A$ & $\mathrm{O} 14: \mathrm{H} 27$ & 20 & Diarrhoea \\
\hline D2776 & EAggEC & aat $A$ & O128abc: H12 & 31 & Diarrhoea \\
\hline D2772 & EAggEC & aat $A$ & $\mathrm{O}$ rough : $\mathrm{H} 10$ & 26 & Diarrhoea \\
\hline D2759 & EAggEC & aat $A$, ast $A$ & $\mathrm{O}$ rough: $\mathrm{H} 10$ & 24 & Diarrhoea \\
\hline D2756 & EAggEC & aat $A$, ast $A$ & $\mathrm{O} 15: \mathrm{NM}$ & 21 & Diarrhoea \\
\hline D2767 & EAggEC & aat $A$, ast $A$ & $\mathrm{O} 143: \mathrm{H} 3$ & 32 & Diarrhoea \\
\hline D2771 & EAggEC & aat $A$, ast $A$ & $\mathrm{O} 176: \mathrm{H} 34$ & 37 & Diarrhoea \\
\hline D2816 & EIEC & EIEC, ipaH & $\mathrm{O}$ rough : NM & 27 & Diarrhoea \\
\hline D2818 & EIEC & EIEC, ipaH & O164:NM & 35 & Diarrhoea \\
\hline D2842 & EIEC & ipaH & OX186:NM & 38 & Diarrhoea \\
\hline D2677 & ETEC & eltB, est $A \mathrm{~h}$ & O6 : H16 & 1 & Control \\
\hline D2671 & ETEC & eltB & $\mathrm{O} 15: \mathrm{H} 51$ & 22 & Diarrhoea \\
\hline D2676 & ETEC & eltB, est $A \mathrm{~h}$ & O6:H16 & 1 & Diarrhoea \\
\hline D2673 & ETEC & est $A \mathrm{~h}$ & O6:H16 & 1 & Diarrhoea \\
\hline
\end{tabular}

NM, Non-motile; NT, not typable by PFGE (the gel was smeared); O rough, autoagglutinable; $\mathrm{O}+$, not typable.

${ }^{\star}$ Two serotypes belonging to classical typical EPEC serotypes (Trabulsi et al., 2002). 
most enterotoxin-producing strains isolated from clinical samples are E. coli (Jertborn \& Svennerholm, 1991; Nataro \& Kaper, 1998).

Pathogenic group, virulence genes, serotype and PFGE patterns of isolates from cases and controls are shown in Table 4. Two strains were not typable by PFGE and resulted in smears on the gels in repeated testing. A total of 20 serotypes was isolated from 22 cases and 18 controls. EIEC strains were only isolated from cases of diarrhoea, one of which had a presumptive new $\mathrm{O}$ antigen (OX186), currently under investigation. O15:NM aatA and ast $A$ were isolated from one case and one control. Two $\mathrm{O}$ rough: $\mathrm{H} 10$ strains - one aatA and ast A, one aat $A$ - were isolated from cases. O171: NM aatA and EAF was isolated from one control and $\mathrm{O} 171: \mathrm{H} 7$ aatA of less than $75 \%$ similarity by PFGE was isolated from one case (Fig. 3). Two cases and one control of O6:H16 were $95 \%$ similar by PFGE (Fig. 3). Only two eae-positive strains belonged to the classical typical EPEC serotypes, O111:H9 and O119:NM (Trabulsi et al., 2002), with the presence of EAF or $b f p A$, and were from cases of diarrhoea. A strain of O157: NM from diarrhoea could represent one of the newly described EPEC serotypes (Scotland et al., 1992; Makino et al., 1999). Of particular interest was the finding that the plasmid gene aat $A$ - thought to be a specific marker for the most virulent typical EAggEC strains - was found together with the EPEC plasmid marker EAF in two strains from controls. The significance of this finding is unclear, but illustrates the difficulties in categorizing DEC. Neither

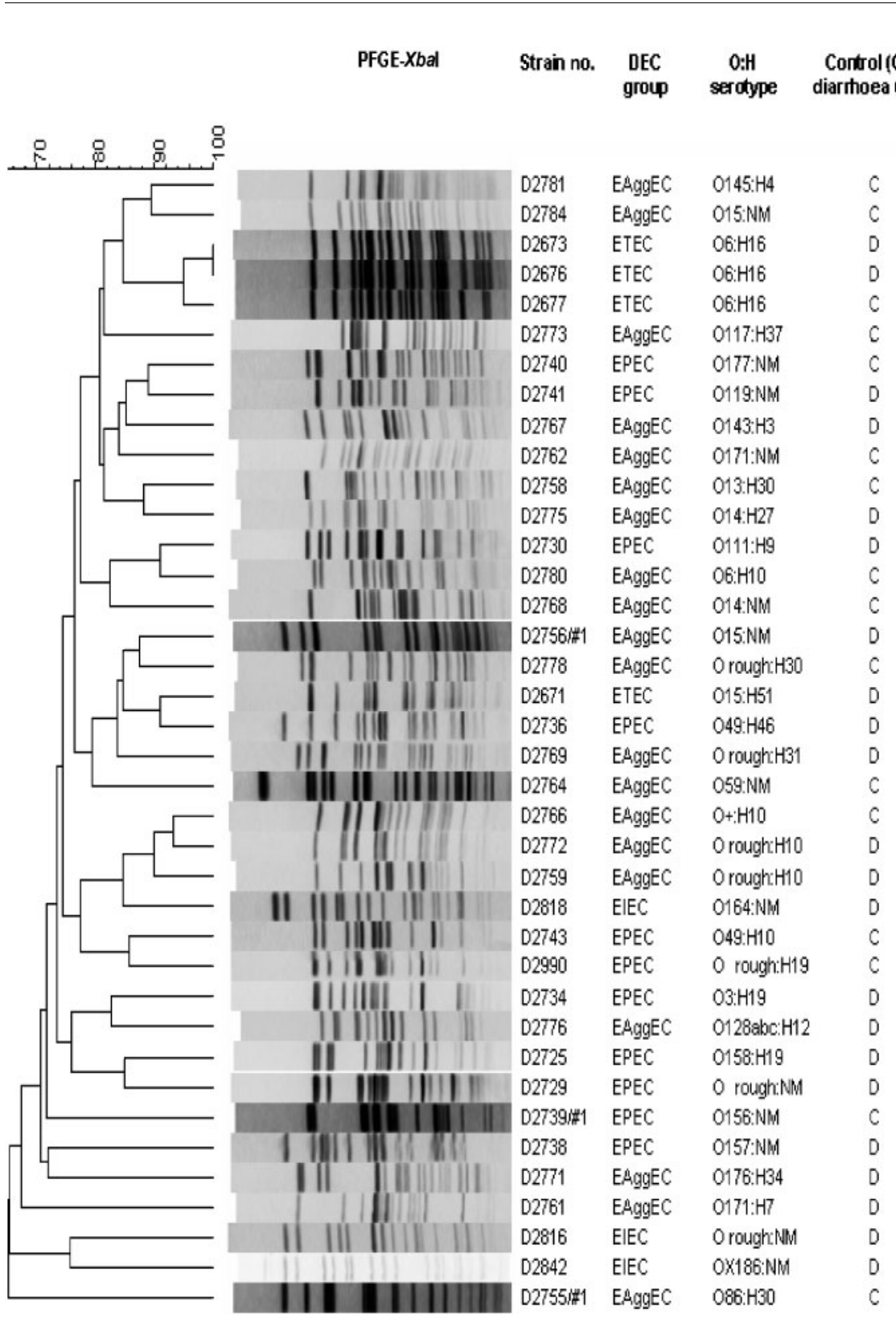

Fig. 3. Dendrogram of 38 Escherichia coli strains based on PFGE typing patterns produced using the band-based dice similarity coefficient and UPGMA. D, Diarrhoea; C, control. 
serotyping nor PFGE revealed any significant similarities between isolates from either cases or controls. Similarly, no differences were observed among isolates from cases and controls. Strains of the same serotype from cases and controls were low in similarity (67\%) by PFGE (Fig. 3). However, three EAggEC strains $(\mathrm{O}+: \mathrm{H} 10$ from one control and two O rough: $\mathrm{H} 10$ from cases) were $90 \%$ similar and two EPEC (O177:NM and O119:NM) were closely related with $89 \%$ similarity in their PFGE patterns. Such trends have been observed previously among EPEC, ETEC and EAggEC strains in India (Kahali et al., 2004).

\section{Antimicrobial susceptibility testing}

The overall results from the antimicrobial susceptibility testing for DEC are shown in Fig. 4. The trend of resistance was different among DEC types. One ETEC strain was multi-resistant to NAL, CHL, SMX, STR, TET and TMP, with the remaining three ETEC strains found to be sensitive to all antimicrobials tested. Resistance to AMP, SMX, STR, TET and TMP was shown by $71-86 \%$ of EAggEC. Six eae positives (including three EPEC strains) were resistant to AMP, SMX and TMP; four eae positives (including three EPEC strains) and five eae positives (including three EPEC strains) were resistant to TET and STR, of which two strains were multi-resistant to seven antimicrobials including NAL and GEN. One out of three EIEC strains was sensitive to all antimicrobials, whilst the two remaining EIEC strains were resistant to AMP, SMX, STR and TMP, and showed intermediate resistance to CEP. All Shigella strains were resistant to SMX, SPE, STR, TET and TMP. These patterns of multiresistance have been observed by others (Anh et al., 2001; Nguyen et al., 2005b). Testing for all antimicrobials commonly used for diarrhoea treatment (SMX, TMP, TET, SPE and STR) resulted in resistance values twice as

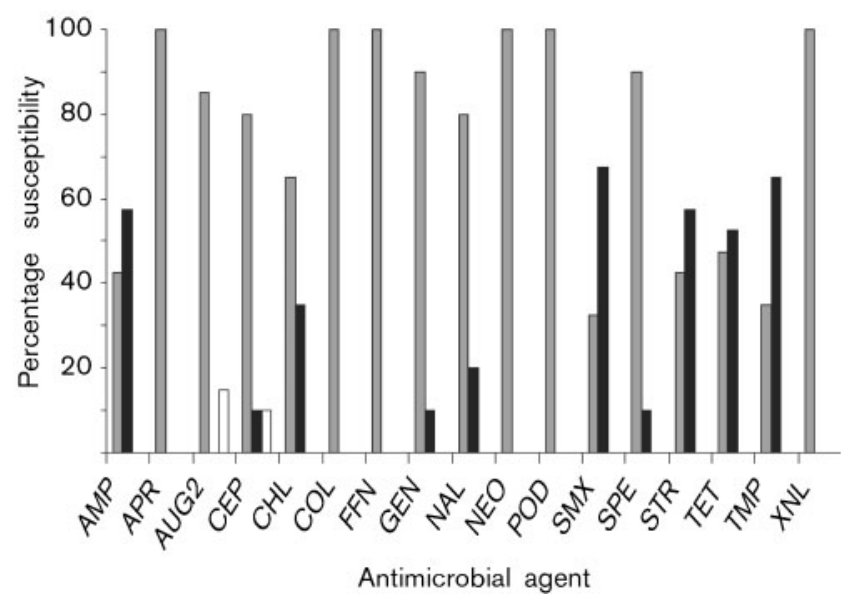

Fig. 4. Antimicrobial susceptibilities of DEC strains. For antimicrobial agent abbreviations see Table 2. Grey bars, sensitive; black bars, resistant; white bars, intermediate. high as the breakpoint values $(>1024,>32,>32,>256$ and $>64 \mu \mathrm{g} \mathrm{ml}^{-1}$, respectively), which is in accordance with other studies, and showed a low activity of these antimicrobials against DEC and Shigella strains (Nguyen et al., 2005b). Therefore, local information about antimicrobial resistance should be used in clinical management, and treatment guidelines should be updated.

\section{Conclusions}

Our further characterization of DEC strains showed that their serotypes were highly heterogeneous and were not typical of any of the known DEC pathotypes except for two typical EPEC strains from children with diarrhoea. From the results of serogroups, virulence genes, antimicrobial profiles and PFGE patterns, our study showed that E. coli strains of the same pathotype or the same serotype are not monophyletic, and do not cluster according to any of the features analysed in this study. To our knowledge, this is first report regarding clonal analysis employing a molecular approach on DEC strains from cases of diarrhoea in Vietnam. From the observed set of strains, it could be inferred that the DEC strains exhibited a high degree of heterogeneity in their genetic make-up. However, prospective molecular epidemiological studies in several locations are required before arriving at any conclusion. These studies are ongoing.

The present study was conducted in an area where a large part of the adult population is exposed to untreated wastewater as part of agricultural activities and fishpond culture. Although conducted with a small number of samples, this study provides a valuable indication of childhood diarrhoeal disease morbidity and aetiology in an understudied area (risk of diarrhoea in a wastewater-use area) and part of the world (Vietnam). However, the incidence of diarrhoea was lower than in many other developing countries ( 0.63 episodes per year), and the overall detection and prevalence of enteric pathogens occurred at roughly similar levels. Thus, living in a wastewater-use area may not have a major influence on the incidence of childhood diarrhoea or on the overall detection and prevalence of enteric pathogens. A more detailed analytical epidemiological study is required to address this aspect further. The study area was located near Hanoi, where drinking water, sanitation and food safety are relatively well developed, and access to health care is better than in other rural areas. This may have contributed to the relatively low diarrhoeal morbidity in the population. Thus, the relative contribution of different pathogens accounting for diarrhoea may vary depending on the specific area. With regard to local intervention, treatment approaches and vaccine development strategies, as well as further studies on aetiology and characterization, are required. This study suggests that, if vaccines for rotavirus and Shigella/EIEC become available as part of a routine schedule for childhood immunization, they could have a major impact on the incidence of diarrhoea and improvement of child health. 


\section{ACKNOWLEDGEMENTS}

This study received financial support from the Danish International Development Agency (DANIDA) through the research capacity building project 'Sanitary Aspects of Drinking Water and Wastewater Reuse in Vietnam', grant no. 104.Dan.8.L. The authors wish to thank Nguyen Thi Binh, President of the Women's Union of Yen So commune and Dr Tran Thi Thu Huong of Yen So, health station for their great efforts in the support and organization of the field activities. Special thanks are given to the seven fieldworkers of Yen So commune for their hard work in data collections during the weekly household visits, and interviews of cases and controls. Special thanks to Tran Minh Thu, Nguyen Thi Be and Nguyen Thi Gam at NIHE for their contributions in the laboratory. Thanks also to Susanne Jespersen, who helped with serotyping and dot blots in Copenhagen.

\section{REFERENCES}

Albert, M. J., Faruque, A. S. G., Faruque, S. M., Sack, R. B. \& Mahalanabis, D. (1999). Case-control study of enteropathogens associated with childhood diarrhea in Dhaka, Bangladesh. J Clin Microbiol 37, 3458-3464.

Ali, M. B., Ghenghesh, K. S., Aissa, R. B., Abuhelfaia, A. \& Dufani, M. (2005). Etiology of childhood diarrhea in Zliten, Libya. Saudi Med J 26, 1759-1765.

Anh, N. T., Cam, P. D. \& Dalsgaard, A. (2001). Antimicrobial resistance of Shigella spp isolated from diarrheal patients between 1989 and 1998 in Vietnam. Southeast Asian J Trop Med Public Health 32, 856-862.

Baqui, A. H., Sack, R. B., Black, R. E., Haider, K., Hossain, A., Alim, A. R. M. A., Yunus, M., Chowdhury, H. R. \& Siddique, A. K. (1992). Enteropathogens associated with acute and persistent diarrhea in Bangladeshi children less than 5 years of age. J Infect Dis 166, 792-796.

Baudry, B., Savarino, S. J., Vial, P., Kaper, J. B. \& Levine, M. M. (1990). A sensitive and specific DNA probe to identify enteroaggregative Escherichia coli, a recently discovered diarrheal pathogen. J Infect Dis 161, 1249-1251.

Bilge, S. S., Clausen, C. R., Lau, W. \& Moseley, S. L. (1989). Molecular characterization of a fimbrial adhesin F1845, mediating diffuse adherence of diarrhea-associated Escherichia coli to HEp-2 cells. J Bacteriol 171, 4281-4289.

Blessmann, J., Van Linh, P., Nu, P. A., Thi, H. D., Muller-Myhsok, B., Buss, H. \& Tannich, E. (2002). Epidemiology of amebiasis in a region of high incidence of amebic liver abscess in central Vietnam. Am J Trop Med Hyg 66, 578-583.

Blom, M., Meyer, A., Gerner-Smidt, P., Gaarslev, K. \& Espersen, F. (1999). Evaluation of Statens Serum Institut enteric medium for detection of enteric pathogens. J Clin Microbiol 37, 2312-2316.

Blumenthal, U. J., Cifuentes, E., Bennett, S., Quigley, M. \& RuizPalacios, G. (2001). The risk of enteric infections associated with wastewater reuse: the effect of season and degree of storage of wastewater. Trans $R$ Soc Trop Med Hyg 95, 131-137.

Bodhidatta, L., Lan, N. T., Hien, B. T., Lai, N. V., Srijan, A., Serichantalergs, O., Fukuda, C. D., Cam, P. D. \& Mason, C. J. (2007). Rotavirus disease in young children from Hanoi, Vietnam. Pediatr Infect Dis J 26, 325-328.

Bolton, F. J., Wareing, D. R. A., Skirrow, M. B. \& Hutchingson, D. N. (1992). Identification and biotyping of Campylobacter. In Identification Methods in Applied and Environmental Microbiology, pp. 151-161. Edited by D. R. G. Jones \& F. A. Skinner. London: Academic Press.

Cifuentes, E. (1998). The epidemiology of enteric infections in agricultural communities exposed to wastewater irrigation: perspectives for risk control. Int J Environ Health Res 8, 203-213.
Cifuentes, E., Gomez, M., Blumenthal, U., Tellez-Rojo, M. M., Romieu, I., Ruiz-Palacios, G. \& Ruiz-Velazco, S. (2000). Risk factors for Giardia intestinalis infection in agricultural villages practicing wastewater irrigation in Mexico. Am J Trop Med Hyg 62, 388-392.

Diaz, A. I., Rivero, R. Z., Bracho, M. A., Castellanos, S. M., Acurero, E., Calchi, L. M. \& Atencio, T. R. (2006). Prevalence of intestinal parasites in children of Yukpa Ethnia in Toromo, Zulia State, Venezuela. Rev Med Chil 134, 72-78 (in Spanish).

Echeverria, P., Taylor, D. N., Lexsomboon, U., Bhaibulaya, M., Blacklow, N. R., Tamura, K. \& Sakazaki, R. (1989). Case-control study of endemic diarrheal disease in Thai children. J Infect Dis 159, 543-548 (erratum J Infect Dis 160, 182).

Echeverria, P., Hoge, C. W., Bodhidatta, L., Tungtaem, C., Herrmann, J., Imlarp, S. \& Tamura, K. (1994). Etiology of diarrhea in a rural community in western Thailand: importance of enteric viruses and enterovirulent Escherichia coli. J Infect Dis 169, 916-919.

El Mohamady, H., Abdel-Messih, I. A., Youssef, F. G., Said, M., Farag, H., Shaheen, H. I., Rockabrand, D. M., Luby, S. B., Hajjeh, R. \& other authors (2006). Enteric pathogens associated with diarrhea in children in Fayoum, Egypt. Diagn Microbiol Infect Dis 56, 1-5.

el Sheikh, S. M. \& el Assouli, S. M. (2001). Prevalence of viral, bacterial and parasitic enteropathogens among young children with acute diarrhoea in Jeddah, Saudi Arabia. J Health Popul Nutr 19, 25-30.

Feenstra, S., Hussain, R. \& van der Hoek, W. (2000). Health Risks of Irrigation with Untreated Urban Wastewater in the Southern Punjab, Pakistan, report 107. Lahore: International Water Management Institute.

Gascon, J., Vargas, M., Schellenberg, D., Urassa, H., Casals, C., Kahigwa, E., Aponte, J. J., Mshinda, H. \& Vila, J. (2000). Diarrhea in children under 5 years of age from Ifakara, Tanzania: a case-control study. J Clin Microbiol 38, 4459-4462.

Girón, J. A., Donnenberg, M. S., Martin, W. C., Jarvis, K. G. \& Kaper, J. B. (1993). Distribution of the bundle-forming pilus structural gene (bfpA) among enteropathogenic Escherichia coli. J Infect Dis 168, 1037-1041.

Habbari, K., Tifnouti, A., Bitton, G. \& Mandil, A. (2000). Geohelminthic infections associated with raw wastewater reuse for agricultural purposes in Beni-Mellal, Morocco. Parasitol Int 48, 249-254.

Hoan, V. Q. (1996). Wastewater Reuse through Aquaculture in Hanoi: Status and Prospects. Bangkok: Asian Institute of Technology.

Huilan, S., Zhen, L. G., Mathan, M. M., Mathew, M. M., Olarte, J., Espejo, R., Khin Maung, U., Ghafoor, M. A., Khan, M. A. \& other authors (1991). Etiology of acute diarrhoea among children in developing countries: a multicentre study in five countries. Bull World Health Organ 69, 549-555.

Isenbarger, D. W., Hien, B. T., Ha, H. T., Ha, T. T., Bodhidatta, L, Pang, L. W. \& Cam, P. D. (2001). Prospective study of the incidence of diarrhoea and prevalence of bacterial pathogens in a cohort of Vietnamese children along the Red River. Epidemiol Infect 127, 229-236.

Jerse, A. E., Yu, J., Tall, B. D. \& Kaper, J. B. (1990). A genetic locus of enteropathogenic Escherichia coli necessary for the production of attaching and effacing lesions on tissue culture cells. Proc Natl Acad Sci U S A 87, 7839-7843.

Jertborn, M. \& Svennerholm, A. M. (1991). Enterotoxin-producing bacteria isolated from Swedish travellers with diarrhoea. Scand J Infect Dis 23, 473-479.

Kahali, S., Sarkar, B., Chakraborty, S., Macaden, R., Deokule, J. S., Ballal, M., Nandy, R. K., Bhattacharya, S. K., Takeda, Y. \& Ramamurthy, T. (2004). Molecular epidemiology of diarrhoeagenic Escherichia coli associated with sporadic cases and outbreaks of diarrhoea between 2000 and 2001 in India. Eur J Epidemiol 19, 473-479. 
Kosek, M., Bern, C. \& Guerrant, R. L. (2003). The global burden of diarrhoeal disease, as estimated from studies published between 1992 and 2000. Bull World Health Organ 81, 197-204.

Levine, M. M., Xu, J.-G., Kaper, J. B., Lior, H., Prado, V., Nataro, J., Karch, H. \& Wachsmuth, I. K. (1987). A DNA probe to identify enterohemorrhagic Escherichia coli of O157:H7 and other serotypes that cause hemorrhagic colitis and hemolytic uremic syndrome. J Infect Dis 156, 175-182.

Makino, S., Asakura, H., Shirahata, T., Ikeda, T., Takeshi, K., Arai, K., Nagasawa, M., Abe, T. \& Sadamoto, T. (1999). Molecular epidemiological study of a mass outbreak caused by enteropathogenic Escherichia coli O157: H45. Microbiol Immunol 43, 381-384.

Mølbak, K., Wested, N., Højlyng, N., Scheutz, F., Gottschau, A., Aaby, P. \& da Silva, M. L. (1994). The etiology of early childhood diarrhea: a community study from Guinea-Bissau. J Infect Dis 169, 581-587.

Mølbak, K., Jensen, H., Ingholt, L. \& Aaby, P. (1997). Risk factors for diarrheal disease incidence in early childhood: a community cohort study from Guinea-Bissau. Am J Epidemiol 146, 273-282.

Mondal, D., Petri, W. A., Jr, Sack, R. B., Kirkpatrick, B. D. \& Haque, R. (2006). Entamoeba histolytica-associated diarrheal illness is negatively associated with the growth of preschool children: evidence from a prospective study. Trans R Soc Trop Med Hyg 100, 1032-1038.

Nataro, J. P. \& Kaper, J. B. (1998). Diarrheagenic Escherichia coli. Clin Microbiol Rev 11, 142-201.

Nataro, J. P., Baldini, M. M., Kaper, J. B., Black, R. E., Bravo, N. \& Levine, M. M. (1985). Detection of an adherence factor of enteropathogenic Escherichia coli with a DNA probe. J Infect Dis 152, 560-565.

NCCLS (1997). Methods for Dilution Antimicrobial Susceptibility Tests for Bacteria that Grow Aerobically. Villanova, PA: National Committee for Clinical Laboratory Standards.

Nguyen, V. M., Nguyen, V. T., Huynh, P. L., Dang, D. T., Nguyen, T. H., Phan, V. T., Nguyen, T. L., Le, T. L., Ivanoff, B. \& other authors (2001). The epidemiology and disease burden of rotavirus in Vietnam: sentinel surveillance at 6 hospitals. J Infect Dis 183, 1707-1712.

Nguyen, T. V., Le Van, P., Le Huy, C. \& Weintraub, A. (2004). Diarrhea caused by rotavirus in children less than 5 years of age in Hanoi, Vietnam. J Clin Microbiol 42, 5745-5750.

Nguyen, T. V., Le Van, P., Le Huy, C., Gia, K. N. \& Weintraub, A. (2005a). Detection and characterization of diarrheagenic Escherichia coli from young children in Hanoi, Vietnam. J Clin Microbiol 43, $755-760$.

Nguyen, T. V., Le, P. V., Le, C. H. \& Weintraub, A. (2005b). Antibiotic resistance in diarrheagenic Escherichia coli and Shigella strains isolated from children in Hanoi, Vietnam. Antimicrob Agents Chemother 49, 816-819.

Nimri, L. F. \& Meqdam, M. (2004). Enteropathogens associated with cases of gastroenteritis in a rural population in Jordan. Clin Microbiol Infect 10, 634-639.

Nishi, J., Sheikh, J., Mizuguchi, K., Luisi, B., Burland, V., Boutin, A., Rose, D. J., Blattner, F. R. \& Nataro, J. P. (2003). The export of coat protein from enteroaggregative Escherichia coli by a specific ATP-binding cassette transporter system. J Biol Chem 278, 4568045689.

Ogunsanya, T. I., Rotimi, V. O. \& Adenuga, A. (1994). A study of the aetiological agents of childhood diarrhoea in Lagos, Nigeria. $J$ Med Microbiol 40, 10-14.

Olesen, B., Neimann, J., Böttiger, B., Ethelberg, S., Schiellerup, P., Jensen, C., Helms, M., Scheutz, F., Olsen, K. E. \& other authors (2005). Etiology of diarrhea in young children in Denmark: a casecontrol study. J Clin Microbiol 43, 3636-3641.
Orlandi, P. P., Magalhaes, G. F., Matos, N. B., Silva, T., Penatti, M., Nogueira, P. A. \& Pereira da Silva, L. H. (2006). Etiology of diarrheal infections in children of Porto Velho (Rondonia, Western Amazon region, Brazil). Braz J Med Biol Res 39, 507-517.

Ørskov, F. \& Ørskov, I. (1984). Serotyping of Escherichia coli. Methods Microbiol 14, 43-112.

PulseNet USA (2004). One Day (24-28 h) Standardized Laboratory Protocol for Molecular Subtyping of Escherichia coli O157:H7, nontyphoidal Salmonella serotypes, and Shigella sonnei by Pulsed-Field Gel Electrophoresis (PFGE). Atlanta, GA: Centers for Disease Control and Prevention.

Savarino, S. J., McVeigh, A., Watson, J., Cravioto, A., Molina, J., Echeverria, P., Bhan, M. K., Levine, M. M. \& Fasano, A. (1996). Enteroaggregative Escherichia coli heat-stable enterotoxin is not restricted to enteroaggregative E. coli. J Infect Dis 173, 1019-1022.

Schmidt, H., Knop, C., Franke, S., Aleksic, S., Heesemann, J. \& Karch, H. (1995). Development of PCR for screening of enteroaggregative Escherichia coli. J Clin Microbiol 33, 701-705.

Scotland, S. M., Willshaw, G. A., Cheasty, T. \& Rowe, B. (1992). Strains of Escherichia coli O157: H8 from human diarrhoea belong to attaching and effacing class of E. coli. J Clin Pathol 45, 1075-1078.

Sethabutr, O., Venkatesan, M., Murphy, G. S., Eampokalap, B., Hoge, C. W. \& Echeverria, P. (1993). Detection of shigellae and enteroinvasive Escherichia coli by amplification of the invasion plasmid antigen $\mathrm{H}$ DNA sequence in patients with dysentery. $J$ Infect Dis 167, 458-461.

Shuval, H. I., Wax, Y., Yekutiel, P. \& Fattal, B. (1989). Transmission of enteric disease associated with wastewater irrigation: a prospective epidemiological study. Am J Public Health 79, 850-852.

Small, P. L. C. \& Falkow, S. (1986). Development of a DNA probe for the virulence plasmid of Shigella spp. and enteroinvasive Escherichia coli. In Microbiology, pp. 121-124. Edited by L. Leive, P. F. Bonventre, J. A. Morello, S. D. Silver, W. C. Wu \& A. Adam. Washington, DC: American Society for Microbiology.

Steele, T. W. \& McDermott, S. N. (1984). The use of membrane filters applied directly to the surface of agar plates for the isolation of Campylobacter jejuni from feces. Pathology 16, 263-265.

Svenungsson, B., Lagergren, A., Ekwall, E., Evengard, B., Hedlund, K. O., Karnell, A., Lofdahl, S., Svensson, L. \& Weintraub, A. (2000). Enteropathogens in adult patients with diarrhea and healthy control subjects: a 1-year prospective study in a Swedish clinic for infectious diseases. Clin Infect Dis 30, 770-778.

Thang, V. Q. (1996). Effects of Sewage Utilization on Fish Farming and Irrigation, Vietnam. Final technical report prepared for the International Development Center (IDRC). Hanoi: Center of Resources and Environmental Studies.

Thomas, A., Smith, H. R., Willshaw, G. A. \& Rowe, B. (1991). Nonradioactively labelled polynucleotide oligonucleotide DNA probes for selectively detecting Escherichia coli strains producing Vero cytotoxins VT1, VT2 and VT2 variant. Mol Cell Probes 5, 129-135.

Trabulsi, L. R., Keller, R. \& Tardelli Gomes, T. A. (2002). Typical and atypical enteropathogenic Escherichia coli. Emerg Infect Dis 8, 508-513.

Van Man, N., Luan, I. T., Trach, D. D., Thanh, N. T., Van Tu, P., Long, N. T., Anh, D. D., Fischer, T. K., Ivanoff, B. \& other authors (2005). Epidemiological profile and burden of rotavirus diarrhea in Vietnam: 5 years of sentinel hospital surveillance, 1998-2003. J Infect Dis 192 (Suppl. 1), S127-S132.

Venkatesan, M. M., Buysse, J. M. \& Kopecko, D. J. (1989). Use of Shigella flexneri ipaC and $i p a H$ gene sequences for the general identification of Shigella spp. and enteroinvasive Escherichia coli. $J$ Clin Microbiol 27, 2687-2691. 
Vu Nguyen, T., Le Van, P., Le Huy, C., Nguyen Gia, K. \& Weintraub, A. (2006). Etiology and epidemiology of diarrhea in children in Hanoi, Vietnam. Int J Infect Dis 10, 298-308.

Wang, H. \& Murdoch, D. R. (2004). Detection of Campylobacter species in faecal samples by direct Gram stain microscopy. Pathology 36, 343-344.

WHO (1987). Manual for Laboratory Investigations of Acute Enteric Infections, pp. 1-113. Edited by the Diarrhoeal Disease Control Programme. Geneva: World Health Organization.
WHO (2006). Guidelines for the Safe Use of Wastewater and Excreta and Greywater. Volume 2: Wastewater Use in Agriculture. Geneva: WHO.

Willshaw, G. A., Smith, H. R., Scotland, S. M. \& Rowe, B. (1985). Cloning of genes determining the production of Vero cytotoxin by Escherichia coli. J Gen Microbiol 131, 3047-3053.

Youssef, M., Shurman, A., Bougnoux, M. E., Rawashdeh, M., Bretagne, S. \& Strockbine, N. (2000). Bacterial, viral and parasitic enteric pathogens associated with acute diarrhea in hospitalized children from northern Jordan. FEMS Immunol Med Microbiol 28, 257-263. 